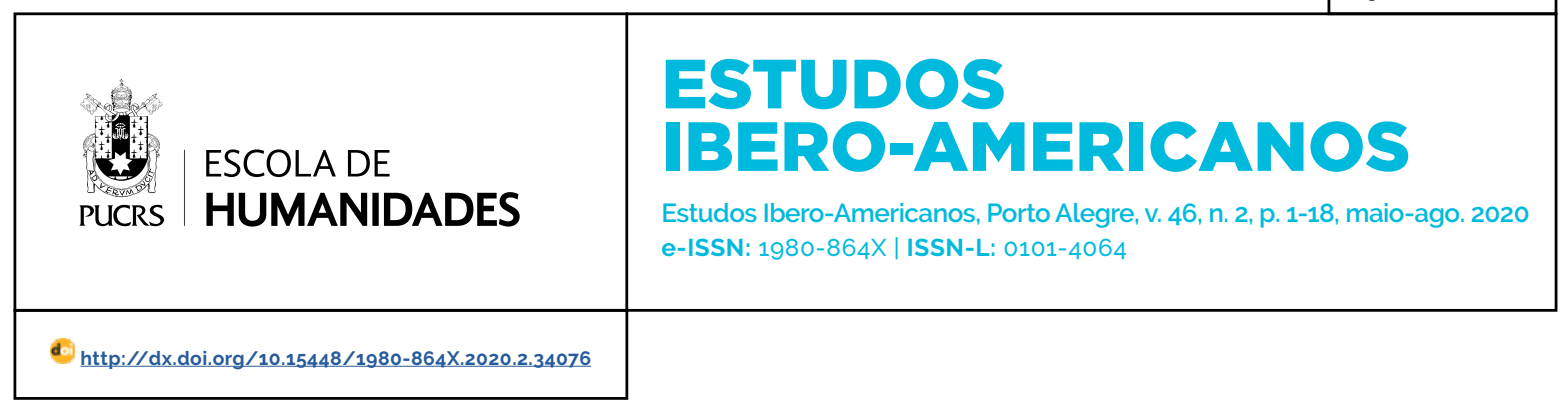

SEÇÃO: DOSSIÊ IMPRENSA, CULTURA E CIRCULAÇÃO DE IDEIAS

\title{
O Conciliador do Maranhão (1821-1823): um periódico no mundo ibero-americano
}

\author{
O Conciliador do Maranhão (1821-1823): a newspaper in the ibero-american world \\ O Conciliador do Maranhão (1821-1823): un periódico en el mundo ibero-americano
}

Marcelo Cheche Galves ${ }^{1}$ orcid.org/0000-0002-7344-9277 marcelochecheppg@gmail.com

Recebido em: 1 jul. 2019 . Aprovado em: 17 mar. 2020. Publicado em: 25 ago 2020.

\section{(c) (1)}

Artigo está licenciado sob forma de uma licença Creative Commons Atribuição 4.0 Internacional.
Resumo: O artigo apresenta aspectos relacionados à criação e à consolidação do jornal O Conciliador do Maranhão (1821-1823), um dos mais regulares e longevos do mundo luso-brasileiro. Em seguida identifica, a partir de cartas, extratos de outros periódicos e de sessões das Cortes portuguesas, os espaços que mereceram especial atenção do jornal, com destaque para Pernambuco e a região do Prata, que permitiram ao jornal articular a dinâmica politica da capitania/ província do Maranhão às experiências políticas diversas, quase sempre tomadas como contraponto para a defesa da monarquia constitucional portuguesa e dos grupos que viabilizavam a existência do jornal. Para explorar tais articulações, prioriza o final do ano de 1821 e início de 1822, tempo de regulamentação das juntas de governo e de eleição na província do Maranhão; e os primeiros meses de 1823, momento de avanço político e militar do projeto de independência concebido a partir do Rio de Janeiro, e que teve como um dos desdobramentos a incorporação da província do Maranhão ao Império do Brasil, em julho de 1823. Palavras-chave: Imprensa. Política. Independências. Ibero-América. Maranhão.

Abstract: The article presents aspects related to the creation and consolidation of the newspaper O Conciliador do Maranhão (1821-1823), one of the most regular and long-lived of the Portuguese-Brazilian world. Then, identifies, from letters, extracts from other newspapers and sessions of the Portuguese Court, the spaces that deserved special attention of the newspaper, highlighting Pernambuco and the region of the Prata, that allowed the newspaper to articulate the political dynamics of the captaincy / province of Maranhão to diverse political experiences, almost always taken as a counterpoint to the defense of the Portuguese constitutional monarchy and of the groups that made possible the existence of the newspaper. In order to explore such articulations, it prioritizes the end of the year 1821 and the beginning of 1822, time of regulation and election of the Government Councils in the Province of Maranhão; and the first months of 1823, a moment of political and military advance of the project of independence conceived from Rio de Janeiro, and that had as one of the unfoldings the incorporation of the province of Maranhão to the Empire of Brazil in July, 1823.

Keywords: Press. Policy. Independences. Ibero-America. Maranhão.

Resumen: El artículo presenta aspectos relacionados a la creación y consolidación del periódico O Conciliador do Maranhão (1821-1823), uno de los más regulares y longevos del mundo luso-brasileño. A continuación, identifica, de las cartas, extractos de otro periódicos y las sesiones de las Cortes portuguesas, los espacios que merecen atención especial do periódico, especialmente Pernambuco y la región de La Plata, lo que permitió el periódico articular la dinámica política de la capitanía / provincia de Maranhão a diversas experiencias políticas, a menudo se toma como contrapunto a la defensa de la monarquía constitucional portuguesa y grupos que hicieron posible la existencia del periódico. Para explorar tales articulaciones, prioriza el final del año 1821 y principios de 1822 , tiempo de regulación de las juntas de gobierno y de elección en la provincia de Maranhão; y los primeros meses de 1823, momento de avance politico y militar 
del proyecto de independencia concebido a partir de Río de Janeiro, y que tuvo como uno de los desdoblamientos la incorporación de la provincia de Maranhão al Imperio de Brasil, en julio de 1823.

Palabras clave: La prensa. Politica. Independencias. Iberoamérica. Maranhão.

\section{Introdução}

Em 1822, a Tipografia de Bulhões, em Lisboa, publicou a Notícia do Conciliador do Maranhão, sintese das homenagens prestadas ao governador do Maranhão Bernardo da Silveira Pinto da Fonseca (1819-1822), substituído em fevereiro daquele ano por uma junta de governo eleita conforme determinação das Cortes portuguesas. Impresso em quatro páginas, o registro é composto por: Auto de Juramento e Posse da Junta de Governo; discursos de agradecimento proferidos por representantes da Junta da Fazenda Nacional e do Corpo de Comércio da cidade de São Luís - que também the homenageara com uma espada; um soneto, escrito por Manuel Ferreira Freire; a resposta de Pinto da Fonseca, em agradecimento; e um texto sem identificação de autoria, intitulado "Despedida que fez o Maranhão ao general Silveira", com um resumo das benfeitorias que teriam caracterizado sua administração.

A rigor, tratava-se da compilação de notícias publicadas em duas edições do jornal o Conciliador do Maranhão: a primeira parte. excetuados o agradecimento de Pinto da Fonseca e a Despedida, foi publicada em 20 de fevereiro de 1822 2: já a "Despedida" foi publicada pelo jornal apenas em 6 de março, poucos dias após Pinto da Fonseca deixar o Maranhão. ${ }^{3}$ Por fim, o texto de agradecimento escrito pelo governador não foi publicado pelo jornal, o que permite supor que estivesse envolvido no projeto de publicação da
Notícia na Tipografia de Bulhões. ${ }^{4}$

Nesse exemplo transparece uma forma menos usual de circulação dos periódicos no momento de transição do mundo luso-brasileiro. Para além dos exemplares que circularam nos dois lados do Atlântico e dos extratos fartamente reproduzidos por outros jornais, nota-se aqui a reorganização de conteúdos, com acréscimos e supressões, indicativo da complexa captação dos circuitos em que palavras e ideias foram ressignificadas, a partir de contextos específicos, articulados pela experiência da modernidade. ${ }^{5}$

No mundo ibero-americano, impactado pela Revolução Francesa, ${ }^{6}$ o compartilhamento dessas experiências pode ser demarcado a partir de evento anterior: a Independência dos Estados Unidos, em 1776. De todo modo, as invasões francesas à Península Ibérica em 1807-1808 aceleraram as transformações politicas, ao mesmo tempo em que integraram mais efetivamente os territórios dos dois lados do Atlântico.

Para o momento, François-Xavier Guerra (2000, p. 17, tradução nossa) observou que "O que todas as regiões da América têm em comum é pertencer ao mesmo conjunto político e cultural".7 Cabe acrescentar a essa observação que tal pertencimento compreendia, ainda, o compartilhamento das expectativas e das incertezas quanto ao futuro, outra caracteristica do tempo (KOSELLECK, 2006, p. 294-296), vividas a partir de um presente em ebulição. Às invasões francesas, sucederam eventos como a transferência da Corte para a América portuguesa, a criação das juntas na América espanhola, a Revolução Pernambucana de 1817 e a Revolução Liberal de 1820.

O ano de 1821, tempo de criação do jornal $O$ Conciliador, foi assim resumido por João Paulo Pimenta (2017, p. 51), no que respeita a América espanhola:

\footnotetext{
2 A reprodução incluiu notas e uma epígrafe com trecho da "Eneida", de Virgílio. Notem-se, na comparação entre os dois textos, pequenos ajustes ortográficos e de disposição das fontes e espaços utilizados.

3 O Conciliador do Maranhão, São Luís, n. 64, 20 fev. 1822, p. 1-3 e O Conciliador do Maranhão, São Luís, n. 68, 6 mar. 1822, p. 2

4 A Tipografia de Bulhões publicou, também em 1822, um folheto com versos escritos por Manuel Ferreira Freire, o mesmo autor do soneto, novamente dedicados ao ex-governador: Versos dedicados à Memória do Ilmo. e Exmo. Senhor Bernardo da Silveira Pinto...

5 Tomo como referência os estudos de Reinhart Koselleck, que situam o final do século XVIII e início do século XIX como tempo de percepção, em regiões da Europa ocidental, de que as experiências de então "jamais haviam sido experimentadas" (2006, p. 274). Adiante, o autor observa que "A consciência do caráter único da época torna-se permanente - um critério daquilo que mais tarde foi chamado de modernidade" (2006, p. 290). Para os limites desse texto, atenho-me à dimensão política das transformações captadas pelo autor.

6 Um debate sobre a relação entre a Revolução Francesa e as revoluções hispano-americanas, com tendência a minimizar o impacto da primeira sobre a segunda, pode ser consultado em François-Xavier Guerra (2000).

7 Do original: Lo que todas las regiones de América tienen entonces em común es su pertenencia a um mismo conjunto politico y cultural.
} 
Em 1821, ela [a realidade] era a do triunfo da revolução na Venezuela, a da irreversibilidade da independência do Rio da Prata e do Chile, e também a das proclamações de independência do Peru, México, Guatemala, Panamá e Santo Domingo. No Brasil, tudo isso foi acompanhado em detalhes.

A parte final da citação transparece uma chave de leitura cara a esse texto. Se a revolução dava o tom das mudanças na América espanhola, as novidades eram acompanhadas na América portuguesa com apreensão e expectativa variáveis. Os espaços da política no mundo iberoamericano, aproximados com a transferência da Corte para o Rio de Janeiro, integravam-se também pelos efeitos que essas novidades provocavam ou poderiam provocar.

Cabe lembrar que, quatro anos antes, a América portuguesa vivera, em Pernambuco, sua própria experiência revolucionária. Nas palavras de Denis Bernardes (2006, p. 205), "a mais ousada e radical tentativa de enfrentamento até então vivido pela Monarquia portuguesa em toda a sua história".

A Revolução Liberal, vitoriosa em agosto de 1820, também trouxe novidades importantes para o mundo luso-brasileiro, ${ }^{8}$ materializadas em aspectos como: a criação de uma assembleia constituinte e o consequente juramento do rei a uma Constituição; a regulamentação da liberdade de imprensa; e a instauração de processos eleitorais, como aqueles que definiram a escolha dos deputados às Cortes ou os membros das juntas de governo, regulamentadas nos últimos meses de 1821.

Contudo, as fissuras provocadas ou agravadas pela Revolução de 1820 tornaram-se evidentes já no ano seguinte. Grão-Pará, Bahia, Pernambuco e Maranhão, não por acaso capitanias ${ }^{9}$ do Norte, aderiram ao projeto constitucional à revelia de $\mathrm{D}$. João VI, que jurou a futura Constituição no final de fevereiro de 1821; ${ }^{10}$ em Lisboa, reuniram-se as Cortes, que a partir de agosto de 1821 contaram com a presença dos deputados da América portuguesa - a "diversidade das bancadas do Brasil", observada por Márcia Berbel (1999, p. 80), ${ }^{11}$ não tardaria a evidenciar dissensos que se revelariam incontornáveis.

Outras fissuras, de algum modo articuladas a esse primeiro conjunto, emergiram com o projeto de independência política capitaneado pelo Rio de Janeiro. Resistências importantes caracterizaram a incorporação de quatro províncias: Bahia e Maranhão (julho de 1823), Grão-Pará (agosto de 1823) e Cisplatina (novembro de 1823).

Esse quadro, brevemente esboçado aqui, aponta para inúmeras possibilidades de pesquisa que aproximem esses espaços cruzados por "objetos, ideias, textos, notícias e boatos que de parte a parte eram trocados, modificados, interpretados e recriados" (PIMENTA, 2017, p. 8). Para os limites desse texto, tais entrecruzamentos serão captados a partir do jornal O Conciliador do Maranhão e do diálogo que seus redatores estabeleceram com a dinâmica política de dois desses espaços: Pernambuco e a região do Prata. Quanto ao primeiro, os eventos de 1817 e o debate nas Cortes, quatro anos depois, com a presença de deputados envolvidos no movimento, ofereceram ao jornal a oportunidade, por contraste, de reafirmação da ordem monárquico-constitucional recém-instituida, a partir de uma leitura muito específica dos ditames constitucionais vigentes na capitania; já o Prata proporcionou bons e maus exemplos, dentro e fora do Reino, de convívio com a ordem política que se defendia, invariavelmente lida e interpretada a partir do Maranhão.

Se os espaços, leituras e interesses eram diversos, a linguagem política pode ser compreendida como uma espécie de "elo entre realidades distintas" (PIMENTA, 2017, p. 21), ${ }^{12}$ potencializada pela produção e difusão da palavra impressa na América portuguesa: no Rio

\footnotetext{
8 Conectadas à experiência hispânica por vários vieses, dentre os quais, a Constituição de Cádiz, de 1812, inspiração primeira das Bases para a Constituição do Reino Português, aprovadas em março de 1821.

9 Lembro que as capitanias da América portuguesa passaram a ser províncias, por decisão das Cortes, em fins de setembro/início de outubro de 1821. Aqui, as duas denominações serão utilizadas, conforme o caso.

10 A adesão das quatro capitanias ocorreu entre $1^{\circ}$ de janeiro (Grão-Pará) e 6 de abril (Maranhão) de 1821. Cabe observar que a notícia do juramento de D. João VI a Constituição só chegou ao Maranhão depois da adesão da capitania, razão pela qual recorri à expressão "à revelia". 11 Tal diversidade expressava dinâmicas políticas distintas, no âmbito de pátrias locais, potencializadas pela novidade constitucional, questão aprofundada pela autora em outro estudo, sobre Pernambuco, a partir da experiência de 1817 (BERBEL, 2003). Para a polissemia da palavra "pátria", comum aos jornais da época, ver Marco Morel (2007).

12 Para uma reflexão sobre o papel desempenhado pelas linguagens políticas nesse processo, o autor remete aos estudos de Elias Palti, de 2007.
} 
de Janeiro, a partir de 1808; no Maranhão, de 1821. Sob o impacto do constitucionalismo, a política ganhava novos espaços e formatos nos prelos de Lisboa, mas também de localidades como Recife e Salvador. Tratava-se, agora, de apreender as novidades do tempo, e atribuir-lhes historicidade.

\section{Escrever a História, inscrever-se no debate político}

Os grandes acontecimentos políticos das nações, devendo algum dia entrar nas páginas da História, precisam ser minutados por testemunhas contemporâneas, e desinteressadas, a fim de que a posteridade possa avaliar o mérito ou demérito dos seus cooperadores [.... ${ }^{13}$

Essas foram as primeiras palavras da primeira edição de O Conciliador do Maranhão. Nove dias antes, em 6 de abril, ${ }^{14}$ a capitania incorporavase à Revolução Liberal de 1820, razão precipua para a criação do periódico. Note-se, aqui, a percepção desse episódio como um "grande acontecimento" conectado a um futuro, em que poderia ser mais bem avaliado. Aos homens do presente, especialmente aqueles desprovidos de maiores interesses, caberia a produção dos registros para a posteridade, tarefa para a qual os redatores do jornal se credenciavam.

Escrevendo a história do futuro, ${ }^{15}$ os redatores viviam as incertezas do presente, caracteristica de um tempo revolucionário, e procuravam se adequar. O tempo se acelerava e exigia ações urgentes, como criar um periódico sem poder contar com uma tipografia. Em jogo, estava o controle político da linguagem, típico de tempos que assistiram a ampliação e a politização dos espaços públicos, e que produziram, na definição de Koselleck (2006, p. 300), "batalha em torno de conceitos". Era preciso narrar/conceituar/explicar de modo conveniente o tempo vivido.

O primeiro número de O Conciliador circulou manuscrito, assim como as 33 edições seguintes, até novembro de 1821, momento em que a agora província recebia a primeira tipografia. ${ }^{16}$ Tal celeridade em promover a circulação de um jornal revela o poder creditado à liberdade de expressão - curiosamente desconectada, até novembro de 1821, do ato de imprimir -, elemento-chave para que a política ganhasse as ruas naquele momento.

Outro aspecto a ser ressaltado é o caráter oficial da iniciativa. Os redatores de O Conciliador, José Antonio da Cruz Ferreira Tezo (o padre Tezinho) e Antonio Marques da Costa Soares, eram figuras próximas ao governador Pinto da Fonseca, ${ }^{17}$ que tentava se manter no cargo após a adesão a Revolução Liberal. Homem forjado no Antigo Regime, como permite entrever a descrição do folheto que dá início a esse texto, Fonseca financiou o projeto de difusão de um constitucionalismo concebido às pressas, levado a cabo por redatores que rapidamente tiveram que apropriar-se do vocabulário constitucional, adequando-o a seus interesses imediatos.

Apenas como exemplo, sobre a forma de governo nas capitanias que aderiram ao projeto constitucional, definida pelas Cortes apenas em setembro/outubro de 1821, os redatores sustentaram, já na primeira edição, o seguinte argumento:

[...] qual será mais bem regido nas delicadas circunstâncias em que estão os domínios portugueses? Um país regido por governos compostos de muitos membros, pela maior parte noviços na grande arte de reger o povo, e talvez suspeitosos do mesmo povo, ou governado por um só homem prático nos deveres relativos ao seu cargo, respeitável em virtudes, ativo em

\footnotetext{
3 O Conciliador do Maranhão, São Luís, n. 1, 15 abr. 1821, p. 1.

14 Na edição n. 77, de 6 de abril de 1822, aniversário de um ano da Revolução Liberal no Maranhão, o jornal passou a se chamar apenas O Conciliador.

15 Expressão que dá título ao livro de Cristiane Alves Camacho dos Santos (2017). Chamo atenção, especialmente, para o capítulo 2, em que a autora explora pontos de inflexão, identificados a partir da regulamentação da liberdade de expressão, nas narrativas produzidas por jornais da América portuguesa, em torno das noções de "Brasil" e "Portugal", singularizando, de certo modo, uma História do Brasil, perspectiva que não transparece nas páginas de O Conciliador.

16 Trata-se da Tipografia Nacional do Maranhão. O jornal circulou impresso a partir do n. 35. de 10 de novembro de 1821 . 0 projeto de imprimir posteriormente os trinta e quatro primeiros números parece não ter sido concretizado completamente. As coleções da Biblioteca Nacional (RJ) e da Biblioteca Pública Benedito Leite (MA) não possuem as edições do n. 9 ao 34, o que reforça a hipótese da não impressão desses números, também não localizados na forma manuscrita. Cf. Marcelo Cheche Galves (2015, p. 135).

${ }_{17}$ Costa Soares era o primeiro oficial da Secretaria do Governo de Pinto da Fonseca. Em novembro, com a instalação da Tipografia Nacional do Maranhão, acumulou o cargo de diretor (AVULSOS, 1821).
} 
providências e, sobretudo, amado dos mesmos povos que tem regido? Pode alguém preferir a incerteza do acaso à realidade da experiência? Basta (grifo nosso). ${ }^{18}$

Reunindo essas qualidades, ou não, Pinto da Fonseca governou o Maranhão até o início do ano seguinte. Nesse tempo, deportou algumas dezenas de opositores - voltarei a eles -, e criou as condições para que O Conciliador se transformasse em um grande jornal para os padrões da época, como se verá.

Com a instalação da tipografia, O Conciliador praticamente monopolizou as atividades de impressão.19 Já em dezembro de 1821, o presidente da comissão responsável pela tipografia expôs os argumentos que justificavam a decisão de dar um desconto de $25 \%$ para a impressão do jornal, afirmando ser esse fundamental não apenas para os objetivos políticos da administração, mas para a publicidade dos ofícios, ordens e mais documentos do expediente do governo. O desembargador também apoiou sua decisão no fato de a impressão de O Conciliador ser a "parte mais certa da Receita" da Tipografia (CONCESSÃO, 1821).

Esse apoio oficial possibilitou periodicidade e longevidade incomuns aos jornais coetâneos, impressos na América portuguesa. O jornal circulou regularmente duas vezes por semana, ao longo de 212 edições, até o final de julho de 1823, momento de incorporação da província do Maranhão ao Império do Brasil, projeto ao qual se opôs.

O número de assinantes e assinaturas também chama atenção. Nas edições n. 39, 56, 97, 163, 167 e 190, O Conciliador apresentou listas nominais com centenas de assinantes que, por vezes, se repetiam ao renovar a assinatura do jornal. Ao todo, o jornal contabilizou 636 assinaturas (ou renovações), de 443 diferentes cidadãos (ou de suas firmas), ${ }^{20} 174$ residentes em São Luís. ${ }^{21}$

As listas nominais são indicativas da abrangência do periódico. Dos 443 assinantes, 419 informaram o local de residência. A sistematização desses números revela a existência de assinantes em 18 localidades do Maranhão, algumas delas muito distantes da capital São Luís, como Pastos Bons, com 11 assinantes; revela ainda a abrangência interprovincial, com 31 assinantes nas províncias do Grão-Pará e Rio Negro, Piaui e Ceará, além de um assinante em Portugal e outro na Inglaterra.

Evidentemente, as palavras e ideias publicadas em O Conciliador circulavam de muitas outras formas e eram também o resultado da leitura de um conjunto variado de informações, oriundo de espaços diversos.

Quanto ao primeiro aspecto, cabe registrar que o trabalho exaustivo de Edú Trota Levati (2015, p. 154-160) identificou, a partir de 35 jornais luso-americanos, 30 referências ao jornal 0 Conciliador, ${ }^{22}$ número que o posicionou na $17 .^{\mathrm{a}}$ colocação entre os periódicos citados nominalmente, ${ }^{23}$ em um ranking que também computou referências a jornais impressos em outros espaços, como o Argos, de Buenos Aires, - Courier e o Correio Braziliense, de Londres.

Sobre as informações que abasteciam o jornal, seguramente provinham de origens variadas, incluido os navios que atracavam e partiam do porto de São Luís, "encruzilhada de pessoas e informações", 24 e as rotas fluviais e terrestres que ligavam o Maranhão ao Grão-Pará e Piauí. Por terra e água, palavras e ideias, boatos e notícias, foram partilhadas ou confrontadas. ${ }^{25}$

As notícias sobre a adesão das capitanias do Norte à Revolução Liberal, por exemplo,

\footnotetext{
18 O Conciliador do Maranhão, São Luis, n. 1, 15 abr. 1821, p. 4.

19 As exceções ficam por conta da impressão, entre março e maio de 1822, do periódico A Folha Medicinal do Maranhão e de um conjunto de folhetos e documentos públicos.

20 Para efeito de comparação, o periódico baiano Idade d'Ouro do Brasil possuia menos de 200 assinantes, em 1819. Cf. Maria Beatriz Nizza da Silva (1978, p. 39). Para os jornais do Rio de Janeiro, Isabel Lustosa salientou que raramente ultrapassavam o número de 200 assinantes (LUSTOSA, 2000, p. 28).

21 A relação dos assinantes pode ser consultada em Marcelo Cheche Galves (2015, p. 459-472)

22 Restritas aos anos de 1821 e 1822, em razão do recorte temporal estabelecido pelo autor.

3 O ranking também considerou referências genéricas, como: "Diários / Folhas / Papeis / Gacetas / Gazetas / Jornais / Periódicos de Lisboa" (LEVATI, 2015, p. 154).

24 Expressão emprestada de João Paulo Pimenta (2017, p. 59), que a utilizou com o objetivo de evidenciar a importância dos portos da América ibérica como espaços de circulação dos "assuntos da política".

25 Sob o título Agentes, suportes e vetores da informação, Edú Levati (2015, p. 24-50) reuniu inúmeros exemplos de articulação entre informações oferecidas por pessoas em trânsito e o conteúdo publicado pelos jornais.
} 
circularam em 4 de abril de 1821, com a chegada da galera Jaquiá, vinda da Bahia, com escala em Pernambuco. Na ausência de um periódico que o fizesse, o próprio governador Pinto da Fonseca encarregou-se de construir uma narrativa sobre o impacto da notícia: "[...] em poucas horas ninguém ignorava, e todos aplaudiam, o generoso arrojo dos bahienses; e a federação, e aderência dos pernambucanos" (FONSECA, 1821?, p. 1). ${ }^{26}$

Com a criação de O Conciliador, as narrativas sobre o Norte da América portuguesa tornaramse uma constante. Ademais, noticias sobre dissensões políticas ou considerações sobre os rumos do Reino ganharam espaço com base em informações publicadas por mais de 40 diferentes periódicos, americanos e europeus, ${ }^{27}$ cujos extratos foram reproduzidos e/ou comentados nas páginas do jornal.

Nessa "geografia das fontes dos jornais" (LEVATI, 2015, p. 65), pensada a partir de O Conciliador, chama atenção as referências à província de Pernambuco, menos pelo recurso à transcrição ou comentário sobre jornais lá impressos - por vezes limitados a Aurora Pernambucana, Abelha, Segarrega ou a referências genéricas, como Gazetas de Pernambuco -, que por intermédio de outras práticas, como a transcrição dos debates parlamentes das Cortes portuguesas ou de narrativas, sem o crédito das fontes, sobre o cotidiano da política em Pernambuco; as notícias também chegavam por intermédio do Semanário Cívico, impresso na Bahia.. ${ }^{28}$ Em pauta, a "ameaça republicana", tema recorrente no jornal, explorado adiante.

Tomando como referência novamente os levantamentos produzidos por Edú Trota Levati (2015, p. 176-422), agora relativos a uma espécie de índice toponímico, construido a partir das referências geográficas identificadas nos jornais, ${ }^{29}$ parece evidente a importância de Pernambuco, por motivações variadas, nas páginas de 0 Conciliador. A partir de mais de 670 diferentes topônimos, que totalizaram mais de 29 mil referências, ${ }^{30}$ o autor chegou a números que merecem algumas considerações.

TABELA 1 - Capitanias/províncias mais citadas pelo O Conciliador - América portuguesa ${ }^{31}$

\begin{tabular}{ccc}
\hline Lugar* $^{*}$ & Número de referências & $\%$ \\
\hline Rio de Janeiro & 567 & 30,2 \\
Pernambuco/Goyana/Recife/Olinda & 471 & 25 \\
Bahia & 304 & 16,2 \\
Pará/Belém/Grão-Pará & 173 & 9,2 \\
Piauí/Parnaíba/Oeiras/São João da Parnaiba & 156 & 8,3 \\
São Paulo & 139 & 7,4 \\
Minas Gerais & 53 & 2,8 \\
Ceará/Ceará Grande/Fortaleza & 17 & 0,9 \\
Total & 1880 & 100 \\
\hline
\end{tabular}

"Exclui as denominações referentes a lugares do Maranhão.

Fonte: Edições diversas de O Conciliador dos anos de 1821 e 1822.

26 Uma narrativa adaptada do texto citado ocupou quase todas as páginas da primeira edição de O Conciliador do Maranhão, São Luís, n. 1, 15 abr.1821. Existem dúvidas sobre a autoria e o ano de impressão desse documento, nominado Singela e verdadeira narração do começo, progresso e conclusão da Regeneração Política do Maranhão.... Sem assinatura, o registro faz referências, na terceira pessoa, aos dois possiveis autores: Pinto da Fonseca e Rodrigo Pinto Pizarro, seu ajudante de ordens. Contudo, a semelhança entre os argumentos apresentados nesse documento e em outros assinados por Pinto da Fonseca à mesma época reforça a hipótese de que seja o autor.

27 Utilizo como referência o banco de dados construído por Edú Trota Levati (2015) para a realização de sua dissertação de mestrado e gentilmente disponibilizado para esse trabalho. As informações sobre os topônimos identificados em O Conciliador, exploradas a seguir, sustentam-se no mesmo banco de dados.

${ }_{28}$ Cabe ressaltar a proximidade entre as capitanias da Bahia e Pernambuco, no que respeita os episódios de 1817, desde a repressão coordenada em um primeiro momento pelo Conde de Arcos, até a prisão dos envolvidos em cárceres baianos (BERNARDES, 2006, p. 241 359). Para mais informações sobre o Semanário Cívico, fartamente reproduzido pelo O Conciliador, ver Maria Beatriz Nizza da Silva (2008). 29 Nas palavras do autor: "Realizar esta epistemologia das cartografias imaginadas significou utilizar-se do método quantitativo para tabular todas as menções, encontradas nos 35 jornais consultados, a diferentes tipos de espaço: hemisférios, oceanos, ilhas, rios, continentes, paises, provincias, cidades, vilas e arraiais" (LEVATI, 2015, p. 8).

30 Cálculo líquido, que contabilizou apenas uma vez, por edição, cada topônimo identificado (LEVATI, 2015, p. 366-422).

31 Por razões metodológicas, e por se tratar de território em litígio, optei por apresentar os números sobre a Cisplatina apenas na Tabela 2, integrando-a ao que denominei como região do Prata. 
Entre as capitanias/províncias, Pernambuco se destaca como a principal referência, abaixo apenas, e evidentemente, do Rio de Janeiro, centro de autoridade da América portuguesa

Sobre outros espaços, não apresentados na Tabela 1, parece óbvio o fato de a porção europeia do Reino reunir o maior conjunto de referências. Contudo, para os propósitos desse texto, cabe observar apenas dois aspectos dessa articulação Lisboa/Maranhão.

Em primeiro lugar, diferentemente dos debates produzidos na Corte por jornais e folhetos impressos em diversas tipografias a partir de interesses distintos, a produção e circulação de impressos no Maranhão, limitada nesse momento à cidade de São Luís e a uma única tipografia, deu ao debate local contornos específicos. Parte dos dissidentes deportados em abril de 1821 recorreu aos prelos de Lisboa ${ }^{32}$ para imprimir folhetos ou publicar denúncias nos jornais da capital do Reino, narrando as agruras da política provincial, invariavelmente atribuidas ao despotismo de Pinto da Fonseca (GALVES, 2015, p. 126-130). Por seu turno, O Conciliador tratou de reproduzir parcialmente essas denúncias, para em seguida refutá-las, promovendo assim uma interlocução que aproximava esses "insultos impressos"33, proferidos em lados distintos do Atlântico.
Outro aspecto, que nos interessa aqui mais de perto, diz respeito a uma espécie de pedagogia constitucional, construida pelo jornal desde as primeiras edições e que se ocupava em defender a nova ordem e realçar a legalidade das práticas políticas que mantiveram Pinto da Fonseca à frente do governo da capitania, bem como suas qualidades "constitucionais".

Para tanto, mirava no que considerava como bons e maus exemplos de realidades diversas, espaços que possibilitaram aos redatores a adoção de noções como tirania/liberdade e despotismo/constituição, ${ }^{34}$ pares comumente identificados com as perspectivas de atraso/ progresso ou passado/futuro, próprias desse tempo de transição, caracterizado como modernidade. ${ }^{35}$ Ao se inserir nessa linha do tempo, apresentava-se como representante de novas ideias, ressignificadas, evidentemente, a partir da dinâmica política do Maranhão e dos interesses que orientavam o funcionamento do periódico.

Aqui, chama atenção o espaço americano como território de experiências a serem avaliadas. Os dados levantados por Edú Trota Levati (2015), referentes aos Estados Unidos e América espanhola - incluido a Banda Oriental -, indicam as áreas de maior interesse do jornal.

TABELA 2 - O Conciliador - Estados Unidos / América espanhola

\begin{tabular}{rrr}
\hline \multicolumn{1}{l}{ Lugar } & Número de referências & \% \\
\hline Região do Prata ${ }^{36}$ & 60 & 51,4 \\
Estados Unidos/Washington/América do Norte/América inglesa & 34 & 16 \\
México/Nova Espanha & 13.7 & 7 \\
Caracas/Caiena/Chile/Colômbia/Peru & 5.9 \\
Total & 100 \\
\hline
\end{tabular}

Fonte: Edições diversas de O Conciliador dos anos de 1821 e 1822.

\footnotetext{
E também de Londres, por intermédio do Correio Braziliense

Imagem poderosa construída por Isabel Lustosa (2000) em pesquisa que explorou os embates na imprensa da Corte entre 1821 e 1823 Sobre uma "história atlântica dos conceitos políticos", ver a obra seminal organizada por Javier Sebastián (2009), especialmente a introdução e o capítulo 3 .

35 Ensina Koselleck (2006, p. 303), que: “Um critério infalível desta modernidade são seus conceitos de movimento - como indicadores da mudança social e política e como elementos linguisticos de formação da consciência, da critica ideológica e da determinação do comportamento".

${ }_{36}$ Considerei referências como: Cisplatina, Colônia de Sacramento, Corrientes, Entre Rios, Maldonado, Montevidéu, Paraguai, Provincia Cisplatina, Províncias do Rio da Prata, Rio da Prata e Uruguai.
} 
A região do Prata, fronteira mais dinâmica da América portuguesa (PIMENTA, 2017, p. 139153), lidera as referências localizadas, e será retomada adiante.

Quanto aos outros espaços americanos, são vários os exemplos oferecidos pelo O Conciliador sobre os (des)caminhos trilhados naquele presente, invariavelmente conectados a um passado recente. Em uma dessas ocasiões, o jornal positivou a experiência histórica dos Estados Unidos - embora a considerasse inaplicável "entre nós", por diferenças "físicas e morais":37

Americanos do Norte eram ingleses por educação e natureza, acostumados ao trabalho, endurecidos com o rigor do clima, pobres, simples, sem luxo, indiferentes às honras da Corte, já de longo tempo usados às formas da liberdade, unidos entre si, e com facilidade de se mutuamente socorrerem, enfim, sujeitos, e não unidos a uma nação [...] A independência nacional só pode vir da força moral, assim como esta em tudo depende do espírito público iluminado, e de um curso de própria educação. ${ }^{38}$

Nesse ponto, há certa aproximação com os jornais analisados por João Paulo Pimenta (2017. p. 32), que notou a crescente valorização da experiência revolucionária anglo-americana, a partir de 1821, contraponto aos "crimes e monstruosidades" associados à França, característica também presente em O Conciliador. Apenas como exemplo das articulações entre 1789 e 1817, exploradas adiante, o jornal observou que "Na época da Revolução Francesa se introduziram desgraçadamente em Pernambuco (bem como em outras províncias do Brasil), os princípios democráticos [...] que veio a produzir pestiferos frutos em 1817".39

Quanto às independências na América espanhola, saudadas por importantes representantes da imprensa fluminense a partir de 1821 (PIMENTA, 2017, p. 32-33), foram rechaçadas com veemência pelo O Conciliador. Em novembro de 1821, o jornal salientou as atrocidades da guerra entre Colômbia e Espanha, povos "que a natureza gerou irmãos, e as paixões fez inimigos!", caminho diverso do que esperava para o Reino: "Oxalá que a nossa Constituição aperte para sempre com fraternal abraço todos os filhos da grande familia dos portugueses" 40

Sobre o México, cuja solução monárquica apresentava-se desde os primeiros meses de 1821, O Conciliador publicou nas edições n. 60 e 61, de fevereiro de 1822, a "Declaração de Independência do México"41 e os "Artigos da Convenção entre o Chefe dos Independentes e o Vice-Rei da Nova Espanha", datado de 24 de agosto de 1821. Esse segundo documento, componente dos Tratados de Córdoba, significou um passo importante para o reconhecimento da independência, concretizada no mês seguinte (PIMENTA, 2017, p. 116).

De caráter monárquico e legitimista, portanto, afeito aos principios defendidos pelo $O$ Conciliador, em que pese seu propósito de independência política, os documentos reproduzidos não mereceram qualquer comentário por parte dos redatores, tampouco os acontecimentos posteriores a Independência, como a coroação do regente Agustín de Iturbide - alternativa a algum membro da dinastia Bourbon, aguardado até maio de 1822 -, e a sua abdicação, em março de 1823.

Os exemplos de dissensões funcionavam como alerta, aprendizado que também se valia de exemplos internos, especialmente de Pernambuco, em 1817. Como observa João Paulo Pimenta (2017. p. 49): "O ano de 1817 é, nesse sentido, crucial, porque ele trouxe para dentro do Reino Unido português a materialização dos espectros criados pela América espanhola". Em seguida, o autor nos lembra de que 1817 foi também o ano da invasão de tropas portuguesas a Montevidéu. Desde 1808 ,

\footnotetext{
37 Observadas também na edição n. 45, a partir da transcrição de um extrato do Semanário Cívico, da Bahia, de 5 de setembro de 1821 (O Conciliador do Maranhão, São Luís, n. 45, 15 dez. 1821, p. 6).

38 O Conciliador do Maranhão, São Luís, n. 38, 21 nov. 1821, p. 5.

39 O Conciliador do Maranhão, São Luís, n. 37. 17 nov. 1821, p. 3

40 O Conciliador do Maranhão, São Luis, n. 35, 10 nov. 1821, p. 5

41 Conhecida como Plano de Iguala, anunciado por Agustín de Iturbide em 24 de fevereiro de 1821. Cf. João Paulo Pimenta (2017, p.113) O autor aponta para instigantes aproximações entre Brasil e México, ensaiadas a partir da análise da publicação, pelo Revérbero Constitucional Fluminense, de excertos apresentados pelos deputados da Nova Espanha às Cortes de Madri, em junho de 1821, e que recuperam a dinâmica das cisões que levaram à independência, meses depois (2017, p. 109-127).
} 
e agora ainda mais, a América se configurava como espaço da política portuguesa, imbricado por relações que em muito superavam os limites territoriais do Reino na América.

\section{Entre Pernambuco e o Prata}

Luiz Geraldo Silva e João Paulo Pimenta (2010, p. 315) esboçaram estimulantes articulações entre Pernambuco e a região do Prata, fundamentadas no que definiram como proximidades "espaciais e temporais" - vividas mais intensamente a partir de 1808 -, e "molduras institucionais", referência às experiências políticas hispano-americanas que teriam inspirado os rebeldes de 1817.

Como alertaram os autores, não se tratava, evidentemente, de um efetivo risco de ação conjunta envolvendo áreas remotas, mas, sobretudo da influência de "um ambiente notadamente afeito a formas republicanas" (2010, p. 316) e, de outro lado, das expectativas que transpareciam nos jornais em circulação na região do Prata, de que a experiência republicana pudesse se expandir pelo território lusoamericano. Nesse sentido, observaram que a Gazeta de Buenos Ayres lamentou, em 2 de agosto de 1817, o fim do movimento nas "províncias do Norte" da América portuguesa (2010, p.334).42

Para os propósitos desse artigo, cabe observar que essas regiões ofereceram ao O Conciliador, entre 1821 e 1823, a possibilidade retórica de um contraponto republicano, inimigo poderoso, difundido no Prata desde as juntas de 1810 e, segundo os redatores, ainda não erradicado da província de Pernambuco.

Em março de 1823, O Conciliador publicou um curioso aviso: "Quem quiser vender um escravo oficial de pedreiro, não sendo de Pernambuco e nem por lá tenha passado, fale com José Maria Faria de Mattos").43 O conteúdo acionava memórias alimentadas pelo periódico desde, pelo menos, o final de 1821, que associavam Pernambuco à desobediência "democrática e republicana"; 44 também tocava em questão cara às elites da província: em 1821, Antonio Bernardino Pereira do Lago (2001, p. 86-90) calculou em mais de 77\% a população de escravos e libertos do Maranhão. Agora, tropas independentistas avançavam sobre a província, fato que justificou, em 8 de abril, a publicação de edital da junta de governo autorizando cidadãos maranhenses a prender os "emissários dos facciosos do Ceará e Piaui", que seduziam a escravatura, conclamando-a à rebelião (EDITAL, 1823).

Sobre a existência em grandes proporções no Maranhão de escravos que vieram de Pernambuco, cabe lembrar que os acordos firmados por Portugal no contexto do Congresso de Viena, referentes à proibição do comércio de escravos oriundos de portos africanos situados ao norte da Linha do Equador - de onde provinha grande parte da escravaria do Maranhão - tiveram, entre outras consequências, a transformação da cidade de Salvador, e não do Recife, em grande centro de abastecimento desse mercado. Alexandre Ribeiro (2007, p. 323) registrou, para 1817 e 1818 , que "mais da metade dos cativos que partiam da Bahia" tinha o Maranhão como destino final. ${ }^{45}$

Assim, parece haver no trecho do aviso em questão mais uma oportunidade de associação entre Pernambuco e insurgência, que propriamente uma preocupação com a origem do escravo a ser adquirido. Faria de Mattos, a quem o interessado pela venda deveria procurar, era figura conhecida na política da província. Comerciante vinculado ao Corpo de Comércio, que dera apoio a Pinto da Fonseca em 1821, era

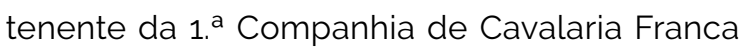
de São Luís, agrupamento que resistiu, até julho de 1823, à incorporação do Maranhão ao Império do Brasil. Com a independência, foi um dos portugueses expulsos pela junta de governo, sob a acusação de ser "nocivo a província" (ATA, 1823).

42 Cabe lembrar que 1817 conectou as duas regiões também por intermédio das punições recebidas pelos derrotados em Pernambuco. Wanderson França (2015, p. 29) fez referência a mais de 800 praças de dois regimentos de primeira linha de Pernambuco, embarcados para Montevidéu após a derrota do movimento. As vicissitudes vividas por parte desses degredados foram exploradas por Maria do Socorro Ferraz Barbosa (2008, p. 119-120), com base em carta publicada no periódico pernambucano Bandeira de Retalhos.

43 O Conciliador, São Luís, n. 176, 19 mar. 1823, p. 4.

44 A forma como as camadas subalternas engajaram-se na cena pública em Pernambuco, entre 1817 e 1848, e foram duramente reprimidas, sob o invariável estigma de perigo social, foi captada por Marcus Carvalho (2005, p. 881-914).

45 Para as transformações na oferta de mão de obra escrava no Maranhão na década de 1810, ver Marcelo Cheche Galves (2019). 
Se nas primeiras edições de $O$ Conciliador, as provincias do Norte que aderiram à Revolução Liberal foram tratadas sob o signo da harmonia, própria de irmãos "descendentes do Tejo", que naquele momento clamavam com a "mesma voz", ${ }^{46}$ as edições a partir de novembro de 1821 transparecem as mudanças ocorridas naqueles seis meses. ${ }^{47}$

Nesse interim, Pernambuco se transformara em antiexemplo poderoso, especialmente pela força que 1817 ganhara naqueles meses, com: o término da devassa instaurada ainda em 1817 e a libertação dos presos, decorrência da Revolução Liberal de 1820; a eleição, em junho, dos deputados pernambucanos para as Cortes portuguesas - entre os 7 eleitos, 3 participaram com destaque do movimento de $1817 ; 48$ a criação da Junta de Goiana, em setembro, que exigiu a saída do governador Luis do Rego Barreto e a convocação de eleições; a saída do governadore a eleição, em 26 de outubro, da junta de governo presidida por Gervásio Pires Ferreira - dos 7 membros da junta, 3 foram presos em 1817.49

O Conciliador acompanhou atentamente a derrocada do governador Luis do Rego Barreto, que manobrara, como Pinto da Fonseca, para permanecer no poder após a adesão de Pernambuco à Revolução Liberal..$^{5}$ Também como Pinto da Fonseca, Rego Barreto pertencia a uma geração de militares envolvidos na resistência à invasão francesa na península e que, na América, assumiram os governos das capitanias: Pinto da Fonseca participou de campanhas no Prata, antes de assumir o governo do Maranhão; Rego Barreto liderou a repressão a 1817 e desde então governava a capitania de Pernambuco.

Essas e outras semelhanças, acrescidas da memória de 1817, fizeram com que os redatores de $O$ Conciliador se interessassem, especialmente, pela dinâmica política vivida em Pernambuco. Experiências compartilhadas aproximavam as duas províncias no contexto do vintismo e permitiram aos redatores acionar tempos distintos e projetar riscos à ordem monárquico-constitucional. No horizonte, contrapunham-se certa leitura constitucional e a possibilidade da separação política.

É difícil precisar, pela já salientada ausência de algumas edições de $O$ Conciliador, a data em que as animosidades envolvendo grupos políticos das duas províncias tomaram uma dimensão pública, bem como a complexidade das razões que as motivaram e alimentaram. Em 17 de novembro, os redatores de $O$ Conciliador afirmaram já ter publicado "há muito a noticia dos fatos acontecidos em Pernambuco".51 Antes, em 11 de setembro de 1821, o deputado pernambucano Muniz Tavares, ${ }^{52}$ na sessão n. 173 das Cortes, assim se pronunciou:

Ontem com a maior amargura ouvi ler dois ofícios, um do Governador do Maranhão, e outro do Governador do Ceará. Do primeiro, evidentemente se colige, que aquela desgraçada provincia, bem digna de melhor sorte, acha-se em inteira opressão; o seu Governador não contente de conservar presos muitos cidadãos, a quem pretende desonrar, com o epíteto de sediciosos, e os quais não duvido que sejam os mais beneméritos, ainda ousa afirmar, perante este Soberano Congresso, que há de usar de medidas mais severas; o que suponho já ser uma Comissão militar.

Em seguida, tratou da delicada questão da instalação de juntas de governo nas províncias, em substituição aos governadores:

Tendo, pois a provincia de Pernambuco recebido há pouco uma sábia e utilissima decisão deste Soberano Congresso, para instalar uma

\footnotetext{
46 As duas expressões aparecem, respectivamente, nas edições número 1 e 7 de 0 Conciliador do Maranhão, de 15 de abril e 6 de maio de 1821 47 Como já observado, as edições de n. 9 a 34, ou seja, de meados de maio a meados de novembro de 1821, provavelmente circularam apenas em versões manuscritas, não localizadas.

48 Francisco Muniz Tavares, Domingos Malaquias Pires Ferreira e Inácio Pinto de Almeida e Castro Cf. Denis Bernardes (2006. p. 381). 49 Gervásio Pires Ferreira, Filipe Néri Ferreira e Antônio José Vitoriano Borges da Fonseca. Cf. Denis Bernardes (2006, p. 399). A determinação das Cortes para eleição de uma junta de governo em Pernambuco data de 1 de setembro de 1821. Lembro que as Cortes, em 29 de setembro e 1 de outubro de 1821, regulamentaram a instituição de juntas de governo em todas as capitanias, agora províncias, da América portuguesa.

50 Denis Bernardes (2006, p. 370-371) caracterizou como "áulica" a adesão de Pernambuco, em março de 1821

51 O Conciliador do Maranhão, São Luís, n. 37, 17 nov. 1821, p. 3

52 A atuação de Muniz Tavares articula os tempos aqui em questão. Preso entre 1817 e 1821, representou Pernambuco nas Cortes portuguesas e na Assembleia Constituinte. Ademais, produziu uma das mais importantes memórias sobre 1817, a História da revolução de Pernambuco em 1817, marco para uma narrativa sobre os liberais no Império do Brasil. Ver lara Lis Schiavinatto e Paula Botafogo Ferreira (2014).
} 
junta provisória removendo-se o ex-governador e capitão general Luiz do Rego Barreto, que tanto a oprimia; requeiro, que esta mesma deliberação se estenda a todo o bispado de Pernambuco, que contém os governos de Alagoas, Parahiba, Rio Grande do Norte, e Ceará; e que continuando na mesma direção igualmente se instale uma junta na província de Oeiras [Piauí], pertencente ao bispado do Maranhão; e outra na capital do mesmo bispado, a cidade de S. Luiz, arrancando-se com a maior brevidade possivel os flagelantes governadores, e ministros de cada uma destas provincias mencionadas (TAVARES, 1821, p. 2.219).

Aqui, o "despotismo" de Pinto da Fonseca era apreendido por dois vieses: a recusa em instalar uma junta de governo - matéria que seria regulamentada pelas Cortes nos dias seguintes -, o que permitia ao narrador aproximá-lo, quanto às práticas, ao governador Luís do Rego Barreto; e o ato de prender e enviar para Portugal, em abril de 1821, dezenas de cidadãos, que regressavam agora, absolvidos, por terem sido presos sem formação de culpa. ${ }^{53}$

Essa ação foi condenada na sessão das Cortes de 2 de outubro de 1821, com uma advertência a Pinto da Fonseca por "arrogar a si as atribuições do poder judiciário [...] a soltar uns e a exterminar outros, sem que estes fossem ouvidos em sua defesa". Tal advertência foi comemorada pelo Correio Braziliense, 54 já O Conciliador, em duas edições, questionou a veracidade da informação, antes de reconhecêla como verdadeira para, em seguida, condenála. 55 O despotismo denunciado para o Maranhão aproximava-o da experiência política vivida em Pernambuco, raciocínio inverso àquele construido pelo 0 Conciliador nas edições localizadas.

Entre as edições n. 35 e 66 (de 10 de novembro de 1821 a 27 de fevereiro de 1822), a política em Pernambuco foi tema recorrente. Por vários expedientes, o assunto permaneceu em pauta. Em 14 de novembro, sem declinar a fonte, o jornal assim resumiu a situação em Pernambuco:
Pernambuco sofre as consequências das terriveis facções; e a ausência do Governador Luis do Rego, mostra quimérico o pretexto que dantes servia aos revoltosos, que chamaram a desgraça e desolação da sua pátria. Desde o momento em que se introduz em qualquer pais o frenesi contagioso das facções, é necessário cada qual renunciar ao seu espírito, à sua razão, e ao seu caráter, para adotar o caráter, a razão, e o espírito da facção; aliás, torna-se cada um sua vitima. [...] Infeliz Pernambuco! Tu também nos pode servir de exemplo memorável destas verdades! Depois que se introduziu no teu seio aquele espirito vertiginoso de facção; não viste teus filhos mortos, presos, sofrendo todos os horrores da desventura? O teu estado atual não é ainda convulsivo? [...] Longe, longe de nós todo o espírito de facção; tapemos os ouvidos às vozes desses exaltados amigos da pátria, que não têm outro merecimento, que um desesperado fanatismo patriótico, sem ser acompanhado de virtude alguma. ${ }^{56}$

Considerando os 7 dias que, em média, durava uma viagem maritima de Recife a São Luís, o jornal registrava o fim do governo de Luís do Rego Barreto, que deixara Pernambuco em 26 de outubro de 1821. Desde o final de agosto, tempo de instalação da Junta de Goiana, se estabeleceu o convivio precário entre dois governos que não se reconheciam, quadro superado apenas com a Convenção de Beberibe e a consequente eleição de uma junta de governo, em 26 de outubro.

Nas palavras dos redatores de O Conciliador, a experiência pernambucana conformava-se como "exemplo memorável" das consequências políticas do contágio por "facções", alimentadas pelos "amigos da pátria". O "tempo da pátria", expressão utilizada por Denis Bernardes (2006. p. 204-217) como referência a 1817, ganhava aqui conotação pejorativa, também comum ao vocabulário daqueles que se opuseram e/ou participaram da repressão ao movimento.

Na edição seguinte, ainda sob o impacto do pronunciamento do deputado Muniz Tavares, ${ }^{57}$ os redatores trataram da "raiz" do problema que

\footnotetext{
53 Sobre esse aspecto, cabe lembrar que a questão das prisões também aproximava os dois governadores. Além dos presos em 1817. Luis do Rego Barreto enviara a Portugal 42 acusados de envolvimento em atentado contra a sua vida, ocorrido em julho de 1821 . Essa questão mobilizou os deputados pernambucanos nas Cortes, que obtiveram a pronta absolvição de todos os acusados, e a autorização para que regressassem a Pernambuco.

54 Correio Braziliense, Londres, n. 164, jan. 1822, p. 64-65.

55 Ver edições n. 53 ( 12 jan. 1822, p. 5-6) e n. 59 (2 fev. 1822, p. 3-4).

56 O Conciliador do Maranhão, São Luis, n. 36, 14 nov. 1821, p. 5.

57 Os efeitos diretos desse pronunciamento transparecem até, pelo menos, o final de 1821, quando o major Rodrigo Pinto Pizarro, ajudante de ordens de Pinto da Fonseca, publicou resposta a Muniz Tavares. Destaco aqui dois questionamentos feitos pelo interlocutor: É déspota o governador do Maranhão porque prendeu quatro homens como os do Capiberibe e Beberibe nos meses de setembro e outubro? Aqui, literalmente: "Seria melhor deixar perpetrar incêndios, mortes e rapinas, como em Pernambuco, Santos, Rio Grande do Sul?" (O Conciliador do Maranhão, São Luís, supl. ao n. 49, 31 dez. 1821, p.1).
} 
assolava Pernambuco: desdea Revolução Francesa, principios democráticos foram semeados, livros eram lidos por adeptos e os resultados foram os "pestiferos frutos de 1817".58 Tais frutos tomavam corpo novamente e se materializavam agora com a instauração da Junta de Goiana, caracterizada, na mesma edição, como "criminosa".59

Em dezembro de 1821, O Conciliador dedicou quase a totalidade de uma edição a Pernambuco. Em um primeiro momento, extratos da ata de sessão das Cortes de 18 de setembro de 1821 foram selecionados e transcritos; em pauta, um documento que informava o fato de o governador Luís do Rego Barreto ter sido ferido por um homem que se julgava ser do "partido da independência". O mesmo documento informava, ainda, a prisão de alguns cúmplices, "já envolvidos nos acontecimentos de 1817", e vinha acompanhado de uma representação de 75 negociantes da praça de Pernambuco, pedindo a permanência do governador. Em seguida, o jornal reproduziu algumas falas dissonantes dos deputados sobre o caráter do governador e o apoio que de fato teria junto aos cidadãos da província. A transcrição termina com a informação de que outra representação, com 90 assinaturas dos oficiais dos corpos militares de Pernambuco, também chegara às Cortes, juntamente com um documento da câmara da vila do Recife, igualmente demonstrando apoio ao governador.

Na mesma edição, entre as notícias chegadas por navios, informou sobre os prejuizos que os ingleses acumularam com a saída de Barreto; em seguida, reproduziu a "Representação dos Habitantes de Pernambuco ao Soberano Congresso", acompanhada por dezenas de assinaturas pela permanência do governador; e, por fim, um extrato do Semanário Cívico, baseado em artigo publicado na Aurora Pernambucana, ${ }^{60}$ contra os "males da República", que se aproximava. ${ }^{61}$

Note-se nesses registros extraidos das edições n. 37 e 45 de 0 Conciliador o recurso a notícias sobre fatos há muito ocorridos, mas apresentados sem essa distinção temporal. O atentado a Luís do Rego, como observado, ocorreu em julho de 1821; já a "criminosa" Junta de Goiana fora instaurada em agosto de 1821 e substituída, no final de outubro, pela junta presidida por Gervásio Pires Ferreira. Nesse momento, preocupava os redatores a aproximação das eleições para os membros da junta de governo do Maranhão, postergada até quando fora possivel, e marcada para fevereiro de 1822.

O constitucionalismo forjado nas primeiras edições do jornal, entre a incorporação à nova ordem política e a manutenção do governo de Pinto da Fonseca, dava lugar agora a um combate aos "sediciosos" de toda ordem, de modo a contribuir para a eleição de figuras próximas a Pinto da Fonseca. Em associação clara entre a experiência de Pernambuco e os riscos de um processo eleitoral mal conduzido, o redator Costa Soares perguntou: "Não poderia suceder que a numerosa escravatura desta província fosse seduzida a crer, que a voz da liberdade era o sinal do seu resgate?"; pouco depois conjeturou: "e se a Revolução [em 1821, no Maranhão] fosse como a de Pernambuco em 1817!!".62

Nesse sentido, refutar os episódios de 1817 cumpria várias funções, dentre as quais: reiterar o constitucionalismo monárquico que caracterizaria o governo de Pinto da Fonseca; zelar pela ordem, ante o florescimento dos frutos de 1817 - especialmente perigoso em uma província sustentada pela mão de obra escrava; e evitar que a futura eleição da junta de governo abrisse caminho para dissensões no Maranhão. Imaginários ou não, os inimigos eram projetados como perigosos e deveriam ser sufocados.

Condenar 1817 cumpria ainda outro propósito: atacar os deputados pernambucanos que, nas Cortes, denunciavam Pinto da Fonseca. Desde a edição n. 43, de 8 de dezembro de 1821, 0

\footnotetext{
O Conciliador do Maranhão. São Luís, n. 37. 17 nov. 1821, p. 3.

Trata-se de extrato do Semanário Cívico, caracterizado pelo o Conciliador como "folha de toda veracidade".

Segundo Denis Bernardes (2006, p. 403), o jornal foi criado pelo governador Luís do Rego Barreto.

O Conciliador do Maranhão, São Luís, n. 45, 15 dez. 1821, p. 2; 4-6.

O Conciliador do Maranhão, São Luís, supl. ao n. 56, 23 jan. 1822, p. 8. Essas considerações integram texto publicado pelo jornal como suplemento às edições n. 56, 61 e 62, sob o título Refutação dos escandalosos folhetos denominados Violências feitas no governo do Maranhão e Manifesto justificativo de M. P. de C., assinado pelo redator Antonio Marques da Costa Soares.
} 
Conciliador reproduziu extratos das sessões das Cortes, propondo, por intermédio dessa seleção, certa leitura dos debates travados no parlamento. No período aqui destacado, o jornal publicou extratos de, pelo menos, 13 sessões das Cortes, com referências específicas à política de Pernambuco. Sem acrescentar comentários aos conteúdos reproduzidos, selecionou um conjunto de moções de apoio ao governador Luís do Rego; também em destaque, o posicionamento da bancada de Pernambuco, na defesa de ações ou preceitos que contrariavam a orientação do jornal, como a retirada do Batalhão de Algarve, estacionado no Recife desde a repressão a 1817, ${ }^{63}$ e a libertação dos presos envolvidos na tentativa de assassinar o governador.

Cabe lembrar que a ordem constitucional possibilitou o envio às Cortes de abaixo-assinados e folhetos denunciando eventuais arbitrariedades dos governadores de província. Advertido em outubro de 1821, como já observado, Pinto da Fonseca enfrentava, além das denúncias proferidas por deputados pernambucanos, acusações endereçadas a outros deputados em Cortes, como Álvaro Xavier da Fonseca Coutinho e Povoas, Francisco Simões Margiochi e D. Romualdo de Souza Coelho, que davam conta de "práticas despóticas".64 Do Maranhão, um abaixo-assinado com 65 assinaturas foi encaminhado às Cortes, em 18 de dezembro de 1821, com outra denúncia, diretamente relacionada à recém instalada Tipografia Nacional do Maranhão, seus usos e abusos:

Tão prodigio é este governador pelos fundos públicos e ávido de lisonja, que tem feito pagar $50 \$ 000$ por mês a Antonio Marques Costa Soares, um dos redatores ostensivos deste abjeto periódico, além de o ter criado Oficial Maior da Secretaria do Governo com ordenado, logo que se fechou o Teatro desta cidade, no qual era tradutor e ao mesmo tempo ensaia- dor dos cômicos, e tudo em remuneração aos nauseantes elogios, e hinos a este general, que fez representar e cantar no dito Teatro, depois do dia 6 de abril, enquanto aberto, e pelas adulações publicadas no mencionado periódico (PROTESTO, 1821, p. 1-2). ${ }^{65}$

Note-se aqui o impacto representado pela novidade da Tipografia no debate político provincial. Era essa a estrutura disponibilizada em apoio a Pinto da Fonseca, e que de algum modo deveria contribuir para que a junta de governo fosse eleita sem sobressaltos.

Gradativamente, assuntos relacionados à Pernambuco perderam importância no jornal, especialmente após a eleição da junta de governo, em 15 de fevereiro de $1822,{ }^{66}$ que garantiu a continuidade no poder do mesmo grupo que apoiara Pinto da Fonseca.

Nos meses seguintes, com as notícias vindas do Rio de Janeiro, os inimigos tomaram outra forma e, curiosamente, as "províncias do Norte" recobraram certa unidade. Apenas como exemplo, em maio de 1822, como reação às noticias sobre a movimentação do regente Pedro por mais autonomia à porção americana do Reino, o Conciliador subiu o tom:

Quem desconhece ser mais interessante para as provincias do Norte do Cabo de S. Roque obedecer antes a Portugal que ao Rio de Janeiro? Os imensos sertões que entre si medeiam, as faz crer em tão longínqua distância, como se ali fosse outro mundo. [...] Haverá porventura, alguém tão louco, que troque o certo, pelo duvidoso? Acaso não temos nós já os nossos direitos declarados, a nossa propriedade garantida, e o que é mais apreciável, os nossos nomes de homens livres inscritos, nas bases da constituição que abraçamos e juramos? ${ }^{67}$

De todo modo, os "perigos republicanos" projetados pelo jornal não desapareceriam tão cedo. Ainda sobre Pernambuco, após a deposição

63 O Batalhão do Algarve deixou o Recife em 30 de novembro de 1821.

64 Esses três deputados receberam folhetos publicados pelo advogado Manoel Paixão dos Santos Zacheo. Radicado no Maranhão, Zacheo foi um atento espectador/interlocutor dos debates do parlamento português. Um ensaio biográfico sobre o personagem pode ser consultado em Yuri Costa e Marcelo Cheche Galves (2011)

${ }_{65}$ Importante observar que o mesmo documento repudiou a forma como O Conciliador vinha "caluniando os povos do Brasil e em particular os nossos irmãos de Pernambuco" (1821, p. 1).

66 Como exemplo da permanência do tema no jornal após a eleição da junta de governo, registro que carta publicada por Antonio Bernardino Pereira do Lago, tenente-coronel do Real Corpo de Engenheiros que prestara serviços em Pernambuco e agora auxiliava Pinto da Fonseca, aproximou os "Martins de lá" aos "Martins de cá", provável referência ao comerciante Domingos José Martins, importante liderança de 1817 (O Conciliador do Maranhão, São Luis, supl. ao n. 65, 23 fev. 1822, p. 2). Para as eleições de fevereiro de 1822 , ver Luís Antonio Vieira da Silva (1972, p. 57-58).

${ }_{67}$ O Conciliador, São Luís, n. 88, 15 maio 1822, p. 3 
de Gervásio Pires Ferreira, em setembro de 1822, o jornal tratou de caracterizar os novos mandatários, grosso modo, como "matadores de $1817^{\prime 68}$ - na mesma edição, o presidente Affonço de Albuquerque foi acusado ainda de atirar no governador Luís do Rego, em 1821; em março de 1823. Pedro Pedroso, governador de armas desde a deposição de Gervásio Pires, foi descrito como um "branco por erro da natureza, e negro por adoção"69

A região do Prata também serviu como recurso ao jornal. No mesmo contexto em que Pernambuco ganhara generosos espaços nas páginas de $O$ Conciliador, os redatores externaram preocupação com os rumos da política na fronteira Sul do Reino. Em novembro de 1821, alertaram para o desastroso resultado provocado pelo desejo de Independência e república na região. Buenos Aires, cidade com "mui pouca escravatura e educação de letras", transformou-se em um "miserável covil da anarquia".70 Note-se aqui a hipótese, implícita, do que poderia acontecer ao Maranhão, com sua numerosa escravatura e pouca instrução, caso a ordem instituida fosse colocada em risco - argumento recorrente, sob outro viés, nas conexões estabelecidas pelo jornal entre Pernambuco e Maranhão.

Na mesma edição, o jornal reproduziu extratos do Argos, de Buenos Aires, com notícias até 12 de julho - indício das distâncias e das dificuldades de interlocução entre esses espaços. O jornal informava que "há quinze meses" a região vivia em "estado de anarquia", resultado na dissolução do "Governo Central", que deu origem a "tantas repúblicas", preâmbulo sucedido por um resumo da situação em dezesseis territórios, incluído Montevidéu. Sobre Buenos Aires, último território a ser abordado, o Argos recuperou o histórico recente de "doze revoluções acontecidas, em dez meses, e de vinte governos durante o mesmo período; de seis invasões sanguinolentas e desoladoras", contraponto de "algum sossego", conquistado nos últimos seis meses. ${ }^{71}$

As notícias davam conta do fracasso da experiência de poder central, encerrada em fevereiro de $1820 ; 7^{72}$ expressavam ainda a relação do Argos com o governo de Buenos Aires, espaço que também se constituía como centro privilegiado para as considerações de seus redatores. ${ }^{73}$ Para $O$ Conciliador, interessava enfatizar os ensinamentos dessas experiências, que desaconselhavam movimentações de insubordinação à ordem monárquico-constitucional. Nesse sentido, o Prata oferecia um exemplo-limite sobre um futuro construido a partir de uma ruptura institucional, condição que o aproximava de 1817 e dos "crimes" cometidos em Pernambuco entre 1821 e 1823.

Para realçar os sentidos pretendidos com a extração das notícias do Argos, o jornal reproduziu em seguida extrato do Semanário Cívico, com a sintese desses ensinamentos: "Habitantes do Brasil, e em particular desta província, refleti no terrivel quadro que vos apresento, do estado desgraçado das províncias do Rio da Prata: vede os terriveis efeitos das desavenças, das rivalidades, e da falta de união!"; em seguida, o texto lembrou que, há menos de 15 anos, Buenos Aires era um "entreposto de riquezas", e que agora vivia em "miserável estado".74

Noutro contexto, de avanço das tropas independentistas sobre a província do Maranhão, o Conciliador recorreu novamente ao Semanário Cívico, dessa feita para materializar, sob outro viés, os temores de 1821: "[caso] o Brasil não venha a unir-se a Portugal, como esperamos, virá a ser retalhado em diversos governichos independentes, uns dos outros, como Buenos Aires, e a ser presa fácil de potências estrangeiras; o que nós tantas vezes temos profetizado".75

\footnotetext{
O Conciliador, São Luís, n. 134, 23 out. 1822, p. 4.

O Conciliador, São Luís, n. 175, 15 mar. 1823, p. 3. Informações importantes sobre a atuação de Pedro Pedroso entre 1817 e 1823 podem ser consultadas em Marcus Carvalho (2005, p. 898-899).

70 O Conciliador do Maranhão, São Luís, n. 38, 21 nov. 1821, p. 4.

71 O Conciliador do Maranhão, São Luis, n. 39, 24 nov. 1821, p. 2. As notícias sobre o Prata iniciadas na edição n. 38 tiveram continuidade na edição n. 39 .

72 Maria Elisa Sá (2014, p. 45) caracterizou o momento como de "dissolução deste embrionário corpo político". Sobre os efeitos da crise política de 1820 na região, ver Fabián Herrero (2010)

73 Para as relações entre os responsáveis pelo jornal e o governo de Buenos Aires, entre 1821 e 1825, ver Mariana Lescano (2015)

74 O Conciliador do Maranhão, São Luís, n. 39, 24 nov. 1821, p. 2-3

75 O Conciliador, São Luís, n. 173, 8 mar. 1823, p. 2.
} 
O interesse de O Conciliador pelo Prata pode ainda ter outras motivações, como a atuação militar de Pinto da Fonseca na região, que lhe valeu a nomeação para o governo do Maranhão. ${ }^{76}$ Fonseca chegou ao Brasil em março de 1816. como membro da Divisão de Voluntários Reais, comandada por Carlos Frederico Lecor, que invadiria territórios da Banda Oriental nos meses seguintes e Montevidéu, em 1817.77

É curioso observar certa dificuldade de 0 Conciliador em classificar, do ponto de vista politico-territorial, as novidades que chegavam sobre a região. Invariavelmente, o jornal identificouas como "Notícias Estrangeiras", em que pese o fato de, desde abril de 1820, os portugueses ocuparem "la totalidade del território de la Provincia Oriental" (FREGA, 2011, p. 22). Evidentemente, tratava-se de um território em litígio, cujos projetos compreendiam o mundo luso-brasileiro e hispano-americano, Lisboa e Rio de Janeiro, Madri e Buenos Aires. O Argos, em extrato já citado, concebia Montevidéu como território sob a esfera de influência de Buenos Aires, ideia reproduzida pelo $O$ Conciliador sem contestação.

Foi por intermédio de uma dessas "Notícias Estrangeiras", que o jornal informou, a partir de uma notícia de Londres, de 4 de outubro de 1821 , que cartas vindas de Buenos Aires afirmavam ter ocorrido uma revolução em Montevidéu, e que a província se declarara como parte do Brasil. $\mathrm{Na}$ sequência, e sem declinar a autoria, a notícia alertava para os custos militares dessa decisão, já que a província tinha como vizinhança "tribos vagabundas", que exigiriam grandes despesas com aparato militar. Informou, ainda, duvidar que o governo de Portugal e do Brasil aceitasse pagar preço tão caro. ${ }^{78}$

A notícia remetia a episódios de julho de 1821 , tempo de realização do Congresso Extraordinário, em Montevidéu, que formalizou a adesão do Estado Cisplatino Oriental ao Reino Unido de Portugal, Brasil e Algarves (FREGA, 2011, p. 30).

Um mês depois das cartas de Buenos Aires, e poucos dias após a eleição da junta que substituiu Pinto da Fonseca, O Conciliador recorreu ao Semanário Cívico para oferecer informações mais detalhadas sobre o ocorrido. Atribuindo o feito à "prudência do nosso Soberano Congresso Nacional, organizando a nossa liberal Constituição; auxiliada por um Governador verdadeiramente constitucional", que possibilitou realizar o "que ambicionávamos possuir há três séculos",79 a notícia enfatizava a plena liberdade que os habitantes da região tiveram para optar ou não pela integração ao Reino. Nas edições 58 e 59, ${ }^{80}$ quase que integralmente dedicadas ao tema, 0 Conciliador reproduziu documentos publicados pelo Semanário Cívico, como o ofício do general Lecor (Barão de Laguna) ao chefe político da província de Montevidéu e a ata da primeira sessão do Congresso, datada de 18 de julho de 1821.

Como no caso de Buenos Aires, Montevidéu voltaria a ocupar espaços em O Conciliador no contexto das notícias chegadas do Rio de Janeiro, a partir de outubro de 1822. Em um primeiro momento, o jornal informou que as tropas de Montevidéu "não fazem causa com o Rio de Janeiro, mas com Portugal"; 81 em março de 1823 , tempo de avanço das tropas do Ceará e Piauí sobre o Maranhão, recorreu mais uma vez ao Semanário Cívico, para salientar as resistências ao projeto do Rio de Janeiro, inclusive de Montevidéu, terra dos "bravos Stretits [sic] ${ }^{82}$ portugueses que não reconhecem o Imperador Pedro".83

\footnotetext{
76 Inicialmente, foi nomeado Francisco Homem de Magalhães Quevedo Pizarro, figura importante nas campanhas do Prata. Impossibilitado de assumir o cargo, por motivo de doença, foi substituido por Fonseca, nomeado em maio de 1819. Cf. Luis Antonio Vieira da Silva (1972, p. 58-60) e Rodrigo Pinto Pizarro (1832).

77 No soneto em homenagem a Pinto da Fonseca, citado no início desse texto, o autor lembrou o percurso do governador, da "terra transmontana" a "América distante", referências ao seu local de nascimento (Várzea de Abrunhais, Lamego) e a Montevidéu.

78 O Conciliador do Maranhão, São Luís, n. 47, 22 dez. 1821, p.4.

9 O Conciliador do Maranhão, São Luís, n. 56, 23 jan. 1822, p. 3

8. De 30 de janeiro e 2 de fevereiro de 1822 , respectivamente.

81 O Conciliador, São Luís, n. 129, 5 out. 1822, p. 5. O jornal informa ter extraído a notícia do "Semanário de 22 de agosto".

82 Talvez a intenção fosse escrever "estritos", no sentido de rigorosos ou severos. Problemas técnicos e operacionais eram comuns à imprensa da época.

83 O Conciliador, São Luís, n. 172, 5 mar. 1823, p. 4.
} 


\section{Considerações finais}

As aproximações praticadas até aqui materializaram indícios apontados em pesquisa de base toponímica (LEVATI, 2015), particularmente referenciados em espaços americanos - situados dentro, fora ou nos limites da América portuguesa - e lidos a partir do jornal responsável por quase toda a atividade impressa do Maranhão entre 1821 e 1823. Pernambuco e o Prata, pela frequência com que foram referenciados em $O$ Conciliador e pelos critérios estabelecidos nessa pesquisa, mereceram atenção especial.

Evidentemente, novos olhares sobre esses e outros espaços/impressos poderiam suscitar um sem número de articulações, com variados personagens. Apenas como exemplo, em folheto impresso em Lisboa e dirigido às Cortes, Manoel Paixão dos Santos Zacheo fez duras críticas ao "Ministério do Rio", que transparecem as principais frustrações dos proprietários da província do Maranhão, em relação às expectativas criadas com a vitória da Revolução Liberal de 1820. Para as discussões conduzidas até aqui, interessa-nos observar a aproximação que o autor promove, em tom de ironia, entre o Rio de Janeiro, Pernambuco e Inglaterra, inimigos, cada um a seu modo, da monarquia constitucional portuguesa:

Faltava só para entronar a urna dos destinos contra o Brasil, fazer o Ministério do Rio mais um ou dois tratados de Comércio ou de Amizade com alguma potência da Europa, enviar para ela um embaixador fidalgo, intrigante, e de boas maneiras [Palmela]; levantar uma Relação em Pernambuco; dar mais duas ou três sangrias morais nas veias, para onde se pedia que entrasse sangue, ou enfim abolir o cativeiro dos criollos, primeira e única moeda corrente que aquele tem e muito mais real e decorosa que o preço que os ingleses põem às suas mulheres, e as prostitutas a seus encantos, vagando pelas ruas da Capital (ZACHEO, 1822, p. 2).

A instituição de uma justiça nos moldes de Pernambuco e a abolição da escravidão compunha o mesmo raciocinio, aqui agregado ao "despotismo", que tomava forma a partir do Rio de Janeiro. Quanto aos ingleses, que em 1807 socorreram Portugal e nos anos seguintes financiaram a lavoura escravista no Maranhão, eram tomados agora como inimigos, condição materializada pelo crescente endividamento dos grandes proprietários da provinciajunto a credores ingleses e pela política britânica de restrições ao comércio de escravos, particularmente sentida a partir de 1816. Nas palavras impressas por Zacheo, a escravidão não encontrava seus inimigos entre os insurgentes, como nos exemplos reunidos pelo O Conciliador sobre Pernambuco, mas entre aqueles que, por razões de outra natureza, obstavam o fluxo de escravos para a província.

Zacheo opusera-se a Pinto da Fonseca em abril de 1821, fato que the valeu dissabores que culminaram com a fuga para o Grão-Pará, de onde fez publicar folhetos nos prelos de Lisboa. Os dois personagens viveram a experiência da adesão à Revolução Liberal em lados opostos, mas compartilhavam horizontes comuns em relação ao futuro do Reino, inviabilizados pelo evento da Independência.

Nos primeiros meses de 1823, noutro contexto, viram-se novamente em lados opostos: Zacheo elegera-se deputado pelo Maranhão para a segunda legislatura das Cortes portuguesas, frustrada pela Revolta de Vila Franca, que restabeleceu os poderes absolutos de D. João $\mathrm{Vl}$; Pinto da Fonseca teve expressiva atuação militar nesse episódio, o que the valeu o título de $1 .^{\circ}$ Visconde da Várzea.

\section{Referências}

ATA da Câmara Geral de 15 de setembro de 1823. Arquivo Nacional (AN). Diversos, cx. 741 A, pct. 24,49.

AVULSOS. Arquivo Público do Estado do Maranhão (APEM). Secretaria do Governo, cx. Diferentes Comissões. Presidente da Provincia do Maranhão (1821-1888). [S.l.: s.n.], 1888.

BARBOSA, Maria do Socorro Ferraz. Liberais constitucionalistas entre dois centros de poder: Rio de Janeiro e Lisboa. Tempo, Niterói, RJ, v. 12, n. 24, p. 98-125, jan. 2008. https://doi.org/10.1590/S1413-77042008000100006.

BERBEL, Márcia Regina. A Nação como Artefato: deputados do Brasil nas Cortes Portuguesas, 1821-1822. São Paulo: Hucitec: Fapesp, 1999.

BERBEL, Márcia Regina. Pátria e patriotas em Pernambuco (1817-1822): nação, identidade e vocabulário político. In: JANCSÓ, István (org.). Brasil: formação do Estado e da Nação (1780-1850). São Paulo: Hucitec, 2003. p. 345-363. 
BERNARDES, Denis Antônio de Mendonça. O patriotismo constitucional: Pernambuco, 1820-1822. São Paulo: FAPESP; Recife: UFPE, 2006.

CARVALHO, Marcus Joaquim Maciel de. Os negros armados pelos brancos e suas Independências no Nordeste (1817-1848). In: JANCSÓ, István (org.). Independência: história e historiografia. São Paulo: Hucitec, FAPESP, 2005, p. 881-914.

CONCESSÃO de $25 \%$ de desconto para imprimir o Conciliador (23/12/1821). José Leandro da Silva Sousa. Biblioteca Pública Benedito Leite (BPBL). Manuscrito (Ms.) 239 (245) M1 G2 E9.

(O) CONCILIADOR do Maranhão. São Luís-MA: [s. n.], 1821-1823.

\section{CORREIO Braziliense. Londres. 1822.}

COSTA, Yuri; GALVES, Marcelo Cheche. O Epaminondas Americano: trajetórias de um advogado português na Província do Maranhão. São Luís: Café \& Lápis; Editora UEMA, 2011.

EDITAL da Junta de Governo autorizando que cidadãos maranhenses prendessem pessoas sem documentos, suspeitas de serem emissárias dos facciosos do Ceará e Piaui, 8/4/1823. Biblioteca Pública Benedito Leite (BPBL). Manuscrito (Ms.) 268 (274) M1 G2 E11.

FONSECA, Bernardo da Silveira Pinto da. Singela e verdadeira narração do começo, progresso e conclusão da Regeneração Politica do Maranhão, no glorioso dia 6 de abril de 1821. Sem data e local de impressão. Biblioteca Nacional (BN), Seção de Obras Raras, Col. Benedito Ottoni.

FRANÇA, Wanderson Édipo de. Gente do povo Pernambuco: da Revolução de 1817 à Confederação de 1824. Clio - Revista de Pesquisa Histórica, Recife, n. 33, n. 1, p. 23-44, 2015

FREGA, Ana. Alianzas y proyectos independentistas em los inicios del "Estado Cisplatino". In: FREGA, Ana (coord.). Historia Regional e Independencia do Uruguay. Proceso histórico y revisión crítica de sus relatos. Montevideo: Ediciones de la Banda Oriental S.R.L., 2011. p. 19-63.

FREIRE, Manuel Ferreira. Versos dedicados à Memória do Ilmo. e Exmo. Senhor Bernardo da Silveira Pinto lda Fonseca], ex-governador provisório da província do Maranhão, partindo desta cidade para a de Lisboa no $1^{\circ}$ de março de 1822. Lisboa: Typografia de Bulhões, 1822. Biblioteca Nacional de Portugal (BNP).

GALVES, Marcelo Cheche. "Ao público sincero e imparcial": Imprensa e independência na província do Maranhão (1821-1826). São Luís: Editora UEMA: Café e Lápis, 2015.

GALVES, Marcelo Cheche. Entre a transferência da Corte e a Revolução do Porto: a capitania do Maranhão em tempos de transformações políticas no Império português. In: FALCON, Francisco José Calazans; CARVALHO, Marieta Pinheiro de; SARMIENTO, Érica (org.). Relações de poder no mundo ibero-americano: séculos XVIII-XIX. Rio de Janeiro: Autografia, 2019. p. 229-258.

GUERRA, François-Xavier. Modernidad e independencias: ensayos sobre las revoluciones hispánicas. 3 ed. México: FCE, MAPFRE, 2000. 1992.
HERRERO, Fabián. "Un gobierno federal", "liberal y de principios": La experiencia del gobierno de Manuel Sarratea durante el crítico año de 1820. Andes, Salta, v. 21, n. 2, p. 261-293, dez. 2010.

KOSELLECK, Reinhart. Futuro passado: contribuição à semântica dos tempos históricos. Rio de Janeiro: Contraponto: Ed. PUC-Rio, 2006.

LAGO, Antônio Bernardino Pereira do. Estatística histórico-geográfica da Província do Maranhão. 2 ed. São Paulo: Siciliano, 2001. 1822.

LESCANO, Mariana Paula. La prensa durante el periodo rivadaviano: El Argos de Buenos Aires (1821-1825). Almanack [online], Guarulhos, SP n. 9, p.136-152, 2015. https://doi.org/10.1590/2236-463320150910.

LEVATI, Edú Trota. Os periódicos da Independência e suas geografias politicas: estudo do surgimento do Brasil independente e de sua inserção no contexto mundial (1808-1822). 2015. Dissertação (mestrado) - Programa de Pós-Graduação em História Social, Universidade de São Paulo, 2015.

LUSTOSA, Isabel. Insultos impressos: a guerra dos jornalistas na independência (1821-23). São Paulo: Companhia das Letras, 2000.

MOREL, Marco. Pátrias polissêmicas: República das Letras e imprensa na crise do Império português na América. In: KURY, Lorelay (org.). Iluminismo e Império no Brasil: o Patriota (1813-1814). Rio de Janeiro: Fiocruz, 2007. p.15-39. https://doi.org/10.7476/9788575416037.002.

NOTÍCIA do Conciliador do Maranhão. Lisboa: Tipografia de Bulhões, 1822. Biblioteca Brasiliana Guita e José Mindlin.

PIMENTA, João Paulo Garrido. Tempos e espaços das independências. A inserção do Brasil no mundo ocidental (1780-1830). São Paulo: Intermeios: USP Programa de Pós-Graduação em História Social, 2017.

PIZARRO, Rodrigo Pinto. Carta de um português emigrado acerca do ex-imperador do Brasil e do seu chamado manifesto. Lisboa: 1832 (Paris, 20/2/1832). Biblioteca Nacional (BN), Seção de Obras Raras.

PROTESTO de lealdade e reconhecimento do povo ao Rei. Instituto Histórico e Geográfico Brasileiro (IHGB), Col. Instituto Histórico, lata 400, pasta 10, doc. 2.

RIBEIRO, Alexandre Vieira. O comércio de escravos e a elite baiana no periodo colonial. In: FRAGOSO, João Luis Ribeiro; ALMEIDA, Carla Maria Carvalho; SAMPAIO, Antonio Carlos Jucá de (org.). Conquistadores e negociantes: histórias de elites no Antigo Regime nos trópicos. América lusa, séculos XVI a XVIII. Rio de Janeiro: Civilização Brasileira, 2007. p. 311-335.

SÁ, Maria Elisa Noronha de Sá. Por uma nova ordem de coisas: as reformas rivadavianas na década de 1820 na província de Buenos Aires. Revista Territórios \& Fronteiras, Cuiabá, v. 7, n. 1, p. 43-60, jan./jun. 2014. https://doi.org/10.22228/rt-f.v7i1.309.

SANTOS, Cristiane Alves Camacho dos. Escrevendo a história do futuro: A leitura do passado no processo de Independência do Brasil. São Paulo: Alameda, 2017. 
SCHIAVINATTO, Iara Lis; FERREIRA, Paula Botafogo Caricchio. As rememorações da "bonifácia": entre a devassa de 1822 e o Processo dos cidadãos de 1824. Revista do Instituto Histórico e Geográfico Brasileiro, Rio de Janeiro, v. 175, n. 462. p. 201-238, jan.-mar. 2014.

SEBASTIÁN, Javier (dir.). Diccionario politico y social del mundo ibero-americano. Madrid: Fundación Carolina/ Sociedad Estatal de Conmemoraciones Culturales/ Centro de Estudios Politicos y Constitucionales, 2009.

SILVA, Luiz Geraldo; PIMENTA, João Paulo Garrido. Pernambuco, Rio da Prata e a crise do Antigo Regime na América ibérica: o "caso" de Felix José Tavares Lira. Estudos ibero-americanos, Porto Alegre, v. 36, n. 2, p. 312-342, jul./dez. 2010. https://doi.org/10.15448/ 1980-864X.2010.2.8766.

SILVA, Maria Beatriz Nizza da. A primeira Gazeta da Bahia: Idade d'Ouro do Brasil. São Paulo: Cultrix, 1978.

SILVA, Maria Beatriz Nizza da. Semanário Cívico. Bahia, 1821-1823. Salvador: EDUFBA, 2008.

TAVARES, Francisco Muniz. Pronunciamento na sessão n. 173 das Cortes Gerais e Extraordinárias da Nação Portuguesa, em 11 de setembro de 1821. DIÁRIO das Cortes Geraes e Extraordinárias da Nação Portugueza. Lisboa: Assembleia da República, 1821, p. 2.219. Disponivel em: http://debates.parlamento.pt/?pid=mc. Acesso em: 15 abr.2020.

VIEIRA DA SILVA, Luís Antonio. História da independência da província do Maranhão (1822-1828). 2 ed. Rio de Janeiro: Companhia Editora Americana, 1972 (Col. São Luis, v. 4). 1862.

ZACHEO, Manoel Paixão dos Santos. Ao Soberano Congresso Nacional, nas Cortes Gerais Extraordinárias e Constituintes da Nação Portuguesa. O Epaminondas Americano sobre a Revolução do Maranhão. Lisboa: J. B. Miranda, 1822. Biblioteca do Itamaraty.

\section{Marcelo Cheche Galves}

Doutor em História pela Universidade Federal Fluminense (UFF, Niterói, RJ, Brasil), professor da Universidade Estadual do Maranhão (UEMA), em São Luís, MA, Brasil.

\section{Endereço para correspondência}

Marcelo Cheche Galves

Universidade Estadual do Maranhão

Núcleo de Estudos do Maranhão Oitocentista (NEMO).

Rua da Estrela, 329, Prédio da História.

Centro, 65010-200

São Luís, MA, Brasil. 